\title{
Phylogeography of Chelonus insularis (Hymenoptera: Braconidae) and Campoletis sonorensis (Hymenoptera: Ichneumonidae), Two Primary Neotropical Parasitoids of the Fall Armyworm (Lepidoptera: Noctuidae)
}

\author{
VIOLAINE JOURDIE, ${ }^{1}$ EDUARDO VIRLA, ${ }^{2}$ HENRY MURILLO,${ }^{3}$ JOSÉ MAURICIO S. BENTO, ${ }^{4}$ \\ TED C. J. TURLINGS, ${ }^{1,5}$ AND NADIR ALVAREZ ${ }^{1}$
}

\begin{abstract}
Ann. Entomol. Soc. Am. 103(5): 742-749 (2010); DOI: 10.1603/AN09156
ABSTRACT In a previous study, we observed no spatial genetic structure in Mexican populations of the parasitoids Chelonus insularis Cresson (Hymenoptera: Braconidae) and Campoletis sonorensis Cameron (Hymenoptera: Ichneumonidae) by using microsatellite markers. In the current study, we investigated whether for these important parasitoids of the fall armyworm (Lepidoptera: Noctuidae) there is any genetic structure at a larger scale. Insects of both species were collected across the American continent and their phylogeography was investigated using both nuclear and mitochondrial markers. Our results suggest an ancient north-south migration of $C$. insularis, whereas no clear pattern could be determined for $C$. sonorensis. Nonetheless, the resulting topology indicated the existence of a cryptic taxon within this later species: a few Canadian specimens determined as $C$. sonorensis branch outside a clade composed of the Argentinean Chelonus grioti Blanchard, the Brazilian Chelonus flavicincta Ashmead, and the rest of the C. sonorensis individuals. The individuals revealing the cryptic taxon were collected from Trichoplusia ni (Hübner) (Lepidoptera: Noctuidae) on tomato (Lycopersicon spp.) and may represent a biotype that has adapted to the early season phenology of its host. Overall, the loosely defined spatial genetic structure previously shown at a local fine scale also was found at the larger scale, for both species. Dispersal of these insects may be partly driven by wind as suggested by genetic similarities between individuals coming from very distant locations.
\end{abstract}

KEY WORDS parasitoids, mitochondrial DNA, internal transcribed spacer, Bayesian inference, spatial genetic structure

Patterns of intraspecific spatial genetic structure (SGS) reflect both historical and contemporaneous levels of gene flow among populations. Although it can be difficult to evaluate which factor, or combination of factors, best explains the observed SGS pattern (Barton and Wilson 1996, Waser and Strobeck 1998), it is important to combine our understandings of both the biology of a studied organism and its phylogeographical history to interpret dispersal patterns correctly. This is particularly true when working with species of economical importance.

Genetic structure can result from past or current barriers to dispersal, density fluctuations, dispersal patterns and mating systems (Chesser 1991a,b). In this study, we looked at the phylogeography of Chelonus

\footnotetext{
${ }^{1}$ University of Neuchâtel, Institute of Biology, Emile-Argand 11, Case Postale 158, 2009 Neuchâtel, Switzerland.

${ }^{2}$ PROIMI-Biotecnología, Av. Belgrano y Pje. Caseros (T4001 MBV), Tucumán, Argentina.

${ }^{3}$ University of Windsor, Department of Biological Sciences, 401 Sunset Ave., Windsor, ON, Canada N9B 3P4.

${ }^{4}$ University of São Paulo, LEF-ESALQ/USP, Departamento de Entomologia e Acarologia, Av. Pádua Dias, 11, 13418-900 PiracicabaSP, Brazil.

${ }^{5}$ Corresponding author: e-mail: ted.turlings@unine.ch.
}

insularis Cresson (Hymenoptera: Braconidae) and Campoletis sonorensis Cameron (Hymenoptera: Ichneumonidae), two important parasitoids of, in particular, the fall armyworm, Spodoptera frugiperda J.E. Smith (Lepidoptera: Noctuidae). The fall armyworm is one of the major pests of several economically important crops throughout the American continent (Kranz et al. 1977). It is attacked by several parasitoids (Molina-Ochoa et al. 2003, Hoballah et al. 2004, Murua et al. 2006, Wyckhuys and O'Neil 2006), and its management through biological control could be enhanced with knowledge on the population dynamics of these parasitoids and on their past and present genetic history.

The two parasitoids show different ecologies and behaviors. Chelonus insularis is an egg-larval parasitoid, whereas C. sonorensis attacks larvae. They can be expected to have adapted their searching behavior to the specific stage they attack. Indeed, C. insularis encounters patches of physically defenseless eggs, so it can lay dozens of eggs at once without having to move much. In contrast, C. sonorensis can lay rarely more than one egg per plant visited, because S. frugiperda larvae are often solitary due to their highly cannibal- 
Table 1. Origins of $C$. insularis specimens used for gene sequencing

\begin{tabular}{|c|c|c|c|c|}
\hline \multirow{2}{*}{ Individual } & \multirow{2}{*}{$\begin{array}{l}\text { Geographic } \\
\text { coordinates }\end{array}$} & \multicolumn{3}{|c|}{ GenBank accession nos. } \\
\hline & & $16 \mathrm{~S}$ & $C O I$ & Cyt b \\
\hline Argentina 1 & $27^{\circ} 18^{\prime} \mathrm{S}, 58^{\circ} 55^{\prime} \mathrm{W}$ & GQ252994 & GQ252921 & GQ252943 \\
\hline Argentina 2 & $27^{\circ} 18^{\prime} \mathrm{S}, 58^{\circ} 55^{\prime} \mathrm{W}$ & GQ252995 & GQ252922 & GQ252944 \\
\hline Argentina 3 & $27^{\circ} 18^{\prime} \mathrm{S}, 58^{\circ} 55^{\prime} \mathrm{W}$ & GQ252996 & GQ252923 & \\
\hline Argentina 4 & $27^{\circ} 18^{\prime} \mathrm{S}, 58^{\circ} 55^{\prime} \mathrm{W}$ & GQ252997 & GQ252924 & GQ252945 \\
\hline Argentina 5 & $27^{\circ} 18^{\prime} \mathrm{S}, 58^{\circ} 55^{\prime} \mathrm{W}$ & GQ252998 & GQ252925 & GQ252946 \\
\hline Argentina 6 & $27^{\circ} 18^{\prime} \mathrm{S}, 58^{\circ} 55^{\prime} \mathrm{W}$ & GQ252999 & GQ252926 & GQ252947 \\
\hline Argentina 7 & $27^{\circ} 18^{\prime} \mathrm{S}, 58^{\circ} 55^{\prime} \mathrm{W}$ & GQ253000 & GQ252927 & GQ252948 \\
\hline Brazil 1 & $19^{\circ} 28^{\prime} \mathrm{S}, 44^{\circ} 14^{\prime} \mathrm{W}$ & GQ253001 & GQ252928 & GQ252949 \\
\hline Brazil 2 & $19^{\circ} 28^{\prime} \mathrm{S}, 44^{\circ} 14^{\prime} \mathrm{W}$ & GQ253002 & GQ252929 & GQ252950 \\
\hline Mexico, Colima 1 & $19^{\circ} 16^{\prime} \mathrm{N}, 103^{\circ} 46^{\prime} \mathrm{W}$ & & GQ252930 & GQ252951 \\
\hline Mexico, Colima 2 & $19^{\circ} 16^{\prime} \mathrm{N}, 103^{\circ} 46^{\prime} \mathrm{W}$ & GQ253003 & GQ252931 & GQ252952 \\
\hline Mexico, Jalisco 1 & $19^{\circ} 52^{\prime} \mathrm{N}, 103^{\circ} 33^{\prime} \mathrm{W}$ & GQ253004 & GQ252932 & GQ252953 \\
\hline Mexico, Jalisco 2 & $19^{\circ} 52^{\prime} \mathrm{N}, 103^{\circ} 33^{\prime} \mathrm{W}$ & GQ253005 & GQ252933 & GQ252954 \\
\hline Mexico, Chiapas 1 & $14^{\circ} 43^{\prime} \mathrm{N}, 92^{\circ} 18^{\prime} \mathrm{W}$ & GQ253006 & GQ252934 & GQ252955 \\
\hline Mexico, Chiapas 2 & $14^{\circ} 43^{\prime} \mathrm{N}, 92^{\circ} 18^{\prime} \mathrm{W}$ & GQ253007 & GQ252935 & GQ252956 \\
\hline Mexico, Chiapas 3 & $14^{\circ} 43^{\prime} \mathrm{N}, 92^{\circ} 19^{\prime} \mathrm{W}$ & GQ253008 & GQ252936 & GQ252957 \\
\hline Mexico, Chiapas 4 & $14^{\circ} 43^{\prime} \mathrm{N}, 92^{\circ} 19^{\prime} \mathrm{W}$ & GQ253009 & GQ252937 & GQ252958 \\
\hline Mexico, Veracruz 1 & $20^{\circ} 29^{\prime} \mathrm{N}, 97^{\circ} 32^{\prime} \mathrm{W}$ & GQ253010 & GQ252938 & GQ252959 \\
\hline Mexico, Veracruz 2 & $20^{\circ} 29^{\prime} \mathrm{N}, 97^{\circ} 32^{\prime} \mathrm{W}$ & GQ253011 & GQ252939 & GQ252960 \\
\hline Mexico, Puebla 1 & $20^{\circ} 27^{\prime} \mathrm{N}, 97^{\circ} 38^{\prime} \mathrm{W}$ & GQ253012 & GQ252940 & GQ252961 \\
\hline Mexico, Puebla 2 & $20^{\circ} 27^{\prime} \mathrm{N}, 97^{\circ} 38^{\prime} \mathrm{W}$ & GQ253013 & GQ252941 & GQ252962 \\
\hline Mexico, Puebla 3 & $20^{\circ} 27^{\prime} \mathrm{N}, 97^{\circ} 38^{\prime} \mathrm{W}$ & & GQ252942 & GQ252963 \\
\hline
\end{tabular}

istic behavior (Chapman et al. 2000). It is therefore expected that $C$. sonorensis has to travel much more than C. insularis to find a comparable number of hosts to parasitize. These different life histories may reflect in the phylogeographic patterns of the two species, and we might expect more structuring at a large scale in C. insularis than in C. sonorensis. C. insularis might tend to disperse less than C. sonorensis; therefore, more local structure may arise in this species.

The current study was also motivated by a proximate conclusion from a previous study (Jourdie et al. 2010 ) in which we documented a low level of genetic structure in these two species when performing smallscale analyses, by using microsatellite loci described in Jourdie et al. 2008), for populations of parasitoids collected in Mexico. To go one step further and to resolve patterns of dispersal throughout the New World (at the continental scale), we investigate in this paper whether this lack of structure at a small-scale also occurs at a larger scale (including other samples from the Neotropical as well as from Nearctic areas) using both nuclear and mitochondrial DNA sequences.

\section{Materials and Methods}

Sampling. Insects were collected across the American continent (Tables 1 and 2). C. insularis specimens from Mexico (states of Colima, Jalisco, Puebla, and Veracruz), Brazil (Sete Lagoas) and Argentina (Chaco province) were included in the study. Individuals of C. sonorensis came from Canada and Mexico.

Table 2. Origins of Campoletis spp. specimens used for gene sequencing

\begin{tabular}{|c|c|c|c|c|c|c|}
\hline & \multirow{2}{*}{ Individual } & \multirow{2}{*}{$\begin{array}{l}\text { Geographic } \\
\text { coordinates }\end{array}$} & \multicolumn{4}{|c|}{ GenBank accession nos. } \\
\hline & & & $16 \mathrm{~S}$ & COI & $28 S$ & ITS \\
\hline \multirow{4}{*}{ C. sonorensis } & Canada 1 & $42^{\circ} 18^{\prime} \mathrm{N}, 83^{\circ} 2^{\prime} \mathrm{W}$ & GQ252981 & GQ252908 & GQ252890 & GQ252968 \\
\hline & Canada 2 & $42^{\circ} 18^{\prime} \mathrm{N}, 83^{\circ} 2^{\prime} \mathrm{W}$ & GQ252982 & GQ252909 & GQ252891 & GQ252969 \\
\hline & Canada 3 & $42^{\circ} 18^{\prime} \mathrm{N}, 83^{\circ} 2^{\prime} \mathrm{W}$ & GQ252983 & GQ252910 & GQ252892 & GQ252970 \\
\hline & Canada 4 & $42^{\circ} 18^{\prime} \mathrm{N}, 83^{\circ} 2^{\prime} \mathrm{W}$ & GQ252984 & GQ252911 & GQ252893 & GQ252971 \\
\hline * & Canada 5 & $42^{\circ} 18^{\prime} \mathrm{N}, 83^{\circ} 2^{\prime} \mathrm{W}$ & GQ252985 & GQ252912 & GQ252894 & \\
\hline * & Canada 6 & $42^{\circ} 18^{\prime} \mathrm{N}, 83^{\circ} 2^{\prime} \mathrm{W}$ & GQ252986 & GQ252913 & & \\
\hline \multirow[t]{7}{*}{$*$} & Canada 7 & $42^{\circ} 18^{\prime} \mathrm{N}, 83^{\circ} 2^{\prime} \mathrm{W}$ & GQ252987 & GQ252914 & GQ252895 & \\
\hline & Mexico, Jalisco 1 & $19^{\circ} 52^{\prime} \mathrm{N}, 103^{\circ} 33^{\prime} \mathrm{W}$ & GQ252988 & GQ252915 & GQ252896 & GQ252972 \\
\hline & Mexico, Jalisco 2 & $19^{\circ} 52^{\prime} \mathrm{N}, 103^{\circ} 33^{\prime} \mathrm{W}$ & GQ252989 & GQ252916 & GQ252897 & GQ252973 \\
\hline & Mexico, Jalisco 3 & $20^{\circ} 28^{\prime} \mathrm{N}, 102^{\circ} 12^{\prime} \mathrm{W}$ & GQ252990 & GQ252917 & GQ252898 & GQ252974 \\
\hline & Mexico, Jalisco 4 & $20^{\circ} 28^{\prime} \mathrm{N}, 102^{\circ} 12^{\prime} \mathrm{W}$ & GQ252991 & GQ252918 & GQ252899 & GQ252975 \\
\hline & Mexico, Nayarit 1 & $21^{\circ} 05^{\prime} \mathrm{N}, 104^{\circ} 26^{\prime} \mathrm{W}$ & GQ252992 & GQ252919 & GQ252900 & GQ252976 \\
\hline & Mexico, Nayarit 2 & $21^{\circ} 05^{\prime} \mathrm{N}, 104^{\circ} 26^{\prime} \mathrm{W}$ & GQ252993 & GQ252920 & GQ252901 & GQ252977 \\
\hline \multirow[t]{2}{*}{ C. flavicincta } & Brazil 1 & $19^{\circ} 28^{\prime} \mathrm{S}, 44^{\circ} 14^{\prime} \mathrm{W}$ & GQ252980 & GQ252906 & GQ252888 & GQ252966 \\
\hline & Brazil 2 & $19^{\circ} 28^{\prime} \mathrm{S}, 44^{\circ} 14^{\prime} \mathrm{W}$ & & GQ252907 & GQ252889 & GQ252967 \\
\hline \multirow[t]{2}{*}{ C. grioti } & Argentina 1 & $26^{\circ} 15^{\prime} \mathrm{S}, 65^{\circ} 16^{\prime} \mathrm{W}$ & GQ252978 & GQ252904 & GQ252902 & GQ252964 \\
\hline & Argentina 2 & $26^{\circ} 15^{\prime} \mathrm{S}, 65^{\circ} 16^{\prime} \mathrm{W}$ & GQ252979 & GQ252905 & GQ252903 & GQ252965 \\
\hline
\end{tabular}

\footnotetext{
* Asterisk indicates individuals collected from T. ni (as opposed to S. frugiperda for the other individuals).
} 
Table 3. Primers used for gene sequencing of $C$. insularis and Campoletis spp.

\begin{tabular}{|c|c|c|c|}
\hline Gene & & Sequence & Reference \\
\hline $28 S$ & $\begin{array}{l}\text { F: } 28 \mathrm{~S} \text { D2 f } \\
\text { R: } 28 \mathrm{~S} \text { D2 r }\end{array}$ & $\begin{array}{l}\text { 5'-AGA GAG AGT TCA AGA GTA CGT G-3' } \\
5^{\prime} \text {-TTG GTC CGT GTT TCA AGA CGG G-3' }\end{array}$ & $\begin{array}{l}\text { Belshaw and Quicke (1997) } \\
\text { Campbell et al. (1993) }\end{array}$ \\
\hline ITS & $\begin{array}{l}\text { F: ITS } 4 \\
\text { R: ITS } 5\end{array}$ & $\begin{array}{l}5^{\prime} \text {-TCC TCC GCT TAT TGA TAT GC-3' } \\
5^{\prime} \text {-GGA AGT AAA AGT CGT AAC AAG G-3' }\end{array}$ & White et al. (1990) \\
\hline$C y t b$ & $\begin{array}{l}\text { F: CytB f } \\
\text { R: CytB r }\end{array}$ & $\begin{array}{l}5^{\prime} \text {-TCT TTT TGA GGA GCW ACW GTW ATT AC-3' } \\
5^{\prime} \text {-AAT TGA ACG TAA AAT WGT RTA AGC AA-3' }\end{array}$ & Belshaw and Quicke (1997) \\
\hline $16 \mathrm{~S} r D N A$ & $\begin{array}{l}\text { F: } 16 \mathrm{~S} \mathrm{f} \\
\text { R: } 16 \mathrm{~S} \mathrm{r}\end{array}$ & $\begin{array}{l}5^{\prime} \text {-CAC CTG TTT ATC AAA AAC AT-3' } \\
5^{\prime} \text {-CTT ATT CAA CAT CGA GGT C-3' }\end{array}$ & $\begin{array}{l}\text { Dowton and Austin (1994) } \\
\text { Whitfield (1997) }\end{array}$ \\
\hline COI & $\begin{array}{l}\text { F: C1-J-1859 } \\
\text { R: C1-N-2191 }\end{array}$ & $\begin{array}{l}5^{\prime} \text {-GGA ACT GGA TGA ACA GTA TAT-3' } \\
5^{\prime} \text {-CCA GGT AAA ATT AAA ATA TAA ACT TC-3' }\end{array}$ & Simon et al. (1994) \\
\hline
\end{tabular}

Because no sequences are published for Campoletis except for C. sonorensis, other taxa of the same genus were included as well to evaluate the monophyletic status of the species and their relative position. Specimens of closely related species (i.e., C. grioti from Argentina and C. flavicincta from Brazil) were thus included. All individuals were obtained from S. frugiperd $a$, except for three Canadian individuals (individuals 5, 6, and 7), which emerged from Trichoplusia ni (Hübner) (Lepidoptera: Noctuidae).

Laboratory Protocols. Total genomic DNA was extracted from the wasps' abdomen using the DNeasy tissue kit (QIAGEN GmbH, Hilden, Germany) following the manufacturer's instructions. Total DNA was resuspended in $200 \mu$ l of elution buffer (two elutions of $100 \mu \mathrm{l}$ each).

Two mitochondrial regions (16S and COI) were amplified in both genera, and a third mitochondrial region $(C y t b)$ could be amplified in $C$. insularis. For Campoletis spp., two additional nuclear markers (28S rRNA and ITS2) also were amplified. Primer information is summarized in Table 3.

28S. The forward primer (28S D2 f) from Belshaw and Quicke (1997) and the reverse primer (28S D2 r) from Campbell et al. (1993) were used to obtain an amplified fragment of $427-510 \mathrm{bp}$. The polymerase chain reaction (PCR) conditions were 30 cycles of $98^{\circ} \mathrm{C}$ denaturation $(15 \mathrm{~s}), 49^{\circ} \mathrm{C}$ annealing $(30 \mathrm{~s})$, and $72^{\circ} \mathrm{C}$ elongation $(40 \mathrm{~s})$ with an initial denaturation of $3 \mathrm{~min}$ at $93^{\circ} \mathrm{C}$ and a final elongation at $72^{\circ} \mathrm{C}$ for $3 \mathrm{~min}$.

Internal Transcribed Spacer (ITS). The forward primer ITS 4 and the reverse primer ITS 5 (White et al. 1990) amplified a 1102-1517-bp fragment under the following polymerase chain reaction (PCR) conditions: initial denaturation of $1 \mathrm{~min} 30 \mathrm{~s}$ at $95^{\circ} \mathrm{C} ; 35$ cycles of $35 \mathrm{~s}$ at $95^{\circ} \mathrm{C}, 1 \mathrm{~min}$ at $53^{\circ} \mathrm{C}$ and $2 \mathrm{~min}$ at $72^{\circ} \mathrm{C}$; final extension of $8 \mathrm{~min}$ at $72^{\circ} \mathrm{C}$.

Cytochrome $b \quad(C y t b)$. The wobble primers designed by Belshaw and Quicke (1997) were used to amplify a 231-424-bp fragment. The PCR conditions were 35 cycles of $92^{\circ} \mathrm{C}$ denaturation $(1 \mathrm{~min}), 53^{\circ} \mathrm{C}$ annealing ( $1 \mathrm{~min})$, and $72^{\circ} \mathrm{C}$ extension ( $\left.1 \mathrm{~min}\right)$, with an initial denaturation of $1 \mathrm{~min} 30 \mathrm{~s}$ at $94^{\circ} \mathrm{C}$ and a final extension of $3 \mathrm{~min}$ at $72^{\circ} \mathrm{C}$.

16S. The forward primer from Whitfield (1997) and the reverse primer from Dowton and Austin (1994) yielded an amplified fragment of $409-459 \mathrm{bp}$. The following PCR conditions were used: initial denaturation of $1 \mathrm{~min} 30 \mathrm{~s}$ at $94^{\circ} \mathrm{C}$, followed by 35 cycles of $94^{\circ} \mathrm{C}$ denaturation $(1 \mathrm{~min}), 53^{\circ} \mathrm{C}$ annealing $(1 \mathrm{~min})$ and $72^{\circ} \mathrm{C}$ extension $(1 \mathrm{~min})$, and a final extension of 3 $\min$ at $72^{\circ} \mathrm{C}$.

Cytochrome c Oxidase Subunit 1 (COI). The mitochondrial DNA (mtDNA) COI was partially amplified using C1-J-1859 (forward) and C1-N-2191 (reverse) primers adapted for the bee (Simon et al. 1994). The amplified fragment was between 364 and $392 \mathrm{bp}$. It was obtained through the following PCR conditions: $1 \mathrm{~min}$ $30 \mathrm{~s}$ at $94^{\circ} \mathrm{C}, 35$ cycles of $94^{\circ} \mathrm{C}$ denaturation ( $1 \mathrm{~min}$ ), $50^{\circ} \mathrm{C}$ annealing $(1 \mathrm{~min})$ and $70^{\circ} \mathrm{C}$ extension $(1 \mathrm{~min})$, and final extension of $5 \mathrm{~min}$ at $70^{\circ} \mathrm{C}$.

Data Analysis. The sequences were manually corrected using ChromasPro 1.41 (Technelysium Pty. Ltd., Queensland, Australia) and further aligned using ClustalW 1.4 (Thompson et al. 1994) implemented in BioEdit (Hall 1999). Analyses were run with the default parameters in Clustal (i.e., gap opening $=15$, gap extension $=6.66$, delay divergent $\%=30$, DNA transition weight $=0.50$, and DNA weight matrix $=$ IUB). Alignment was straightforward for all genes as there were no indels. BLAST searches were conducted on all sequences to check for possible contamination.

Selection of Outgroups. Sequences from closely related taxa to both C. insularis and Campoletis spp. were compared to determine which species were more suitable as outgroups. GenBank accession numbers of the sequences used are provided in Table 4. Sequences were obtained in Fasta format from GenBank and converted into Phylip format with ForCon 1.0 (Raes and Van de Peer 1999). Further alignment with $C$. insularis and Campoletis spp. matrices was performed using ClustalW 1.4 (Thompson et al. 1994) implemented in BioEdit (Hall 1999). A phylogenetic tree was then reconstructed using RAxML (Stamatakis 2006, Stamatakis et al. 2008) to determine the closest related outgroup taxa.

Phylogenetic Reconstructions. Once the outgroup was picked, a supermatrix composed of three and four nucleotide partitions respectively for $C$. insularis and C. sonorensis was built using Concatenate (Alexis Criscuolo, http://www.supertriplets.univ-montp2.fr/ PhyloTools.php/). In the supermatrix, taxa in which no sequences were gathered for a given partition were coded as missing values for the corresponding cells 
Table 4. GenBank accession numbers for $C y t b, 16 S \mathrm{rDNA}$, and $C O I$ sequences used to determine the most suitable outgroup taxa in the phylogenetic analyses

\begin{tabular}{|c|c|c|c|}
\hline & $C y t b$ & $16 \mathrm{~S} r D N A$ & COI \\
\hline Chelonus cautus 1 & & & EF555604 \\
\hline Chelonus cautus 2 & & & EF555605 \\
\hline Chelonus cautus 3 & & & EF555606 \\
\hline Chelonus cautus 4 & & & EF555607 \\
\hline Chelonus cautus 5 & & & EF555608 \\
\hline Chelonus cautus 6 & & & EF555609 \\
\hline Chelonus cautus 7 & & & EF555610 \\
\hline Chelonus cautus 8 & & & EF555611 \\
\hline Chelonus sp. 1 & & EU107068 & EU106961 \\
\hline Chelonus sp. 2 & & EU107069 & EU106962 \\
\hline Chelonus sp. 3 & & EU107070 & EU106963 \\
\hline Chelonus sp. 4 & & DQ538554 & DQ538844 \\
\hline Chelonus sp. 5 & & & AF102723 \\
\hline Chelonus sp. 6 & & U68150 & \\
\hline Chelonus sp. 7 & & AY004037 & \\
\hline Chelonus sp. 8 & & AY004038 & \\
\hline Chelonus sp. 9 & & AF003512 & \\
\hline Chelonus sp. 10 & & AF029115 & \\
\hline Chelonus sp. 11 & & & AY165727 \\
\hline Chelonus sp. 12 & Z83639 & & \\
\hline Chelonus inanitus 1 & & DQ538562 & DQ538853 \\
\hline Chelonus inanitus 2 & & AJ535933 & \\
\hline Sathon falcatus & Z83638 & AF102764 & \\
\hline
\end{tabular}

(Wiens and Reeder 1995). Heuristic searches were performed using the three following criteria: maximum parsimony (MP), maximum likelihood (ML), and Bayesian inference. All trees generated were edited with FigTree version 1.1.2 (Andrew Rambaut, http://tree.bio.ed.ac.uk/software/figtree/).

Maximum Parsimony. MP analyses were performed using parsimony ratchet (Nixon 1999) as implemented in PAUPrat (Sikes and Lewis 2001). Based on recommendations by (Nixon 1999), ten independent searches were performed with 200 iterations and $15 \%$ of the parsimony informative characters perturbed. The shortest equally most parsimonious trees were combined to produce a majority-rule consensus tree. To assess the support at each node, non parametric bootstrap analyses were performed using PAUP* version 4.0b10 (Swofford 2002) with 1,000 replicates, tree bisection and reconnection branch swapping, simple sequence addition, MULTREES and holding 10 trees per replicate.

Maximum Likelihood. The ML analysis with the supermatrix treated as a single partition was performed using the RAxML web-server (http://phylobench. vital-it.ch/raxml-bb/) (Stamatakis 2006, Stamatakis et al. 2008). The model used by this software is by default GTR+G. Treefinder (Jobb 2008) also was used to perform a ML analysis and to check for congruency between the two algorithms.

Bayesian Inference. A Bayesian inference analysis (Nylander 2004) was performed on the supermatrix (with each DNA region represented as a separate partition), by using MrBAYES (Huelsenbeck and Ronquist 2001), with substitution models as estimated by MrAIC 1.4.3 (Nylander 2004). Two simultaneous Monte Carlo Markov chains were run for $5 \times 10^{5}$ generations, saving one tree every 100 generations. Stationarity was determined by looking at the average standard deviation of split frequencies. Trees recovered before stationarity being reached were discarded and Bayesian posterior probabilities (BPPs), representing the percentage of times each node was recovered, were calculated from a consensus of the remaining trees. Effective sampling size (ESS) for Markov chain Monte Carlo (MCMC) analyses in both species were calculated with Tracer 1.3 (Rambaut and Drummond 2005).

\section{Results}

Samples. Tables 1 and 2 provide details on how many individuals per species and per location were included in the analyses along with the GenBank accession numbers for all sequences used. All individuals emerged from $S$. frugiperda, except for three Canadian C. sonorensis wasps (individuals 5, 6, and 7), which emerged from T. ni. These T. ni larvae were collected from tomato plants only $\approx 100 \mathrm{~m}$ from the maize plants with the $S$. frugiperda larvae that provided the other four Canadian C. sonorensis individuals. Because the larvae were collected at the same time, it cannot be excluded that some of the parasitoids were from the same mother.

Alignments. Sequences are available in GenBank under accession numbers GQ252888 to GQ253013 (Tables 1 and 2). In C. insularis, two individuals failed to amplify $16 \mathrm{~S}$, one failed to amplify $C y t b$, whereas all individuals amplified for COI. For Campoletis spp., one individual failed in providing satisfactory amplification for both $16 \mathrm{~S}$ and $28 \mathrm{~S}$, three were unsuccessful for ITS, whereas all individuals correctly amplified COI.

Selection of Outgroups. From the phylogenies obtained with the sequences published online, Chelonus inanitus (Hymenoptera: Braconidae) and Venturia canescens (Hymenoptera: Ichneumonidae) were chosen as outgroups for C. insularis and Campoletis, respectively (tree not shown). No Cyt $b$ sequence was available for $C$. inanitus nor was the ITS sequence for $V$. canescens.

Phylogenetic Analyses. For C. insularis, the alignment consisted of 38 variable characters (of 1,190 in total), among which 36 characters were parsimonyinformative. Under the MP criterion, the heuristic search resulted into 188 equally most parsimonious trees of 83 steps (consistency index $[\mathrm{CI}]=0.904$, retention index $[\mathrm{RI}]=0.897$, rescaled consistency $[\mathrm{RC}]=0.811$, and homoplasy index $[\mathrm{HI}]=0.096)$. Regarding probabilistic criteria (i.e., ML and Bayesian inference), the best-fit model was the general time reversible (GTR). The topologies produced during the two ML searches (i.e., RAxML and TreeFinder) were identical and fully congruent with the Bayesian inference partitioned analysis (using a F81 best-fit model of evolution for all partitions). In this latter analysis, average standard deviation of split frequencies reached $1 \%$ after 150,000 MCMC generations, thus the first 1,500 first trees were discarded (burn-in). ESS was $>500$ for all parameters. For Campoletis spp., the alignment comprised 98 variable characters (of 


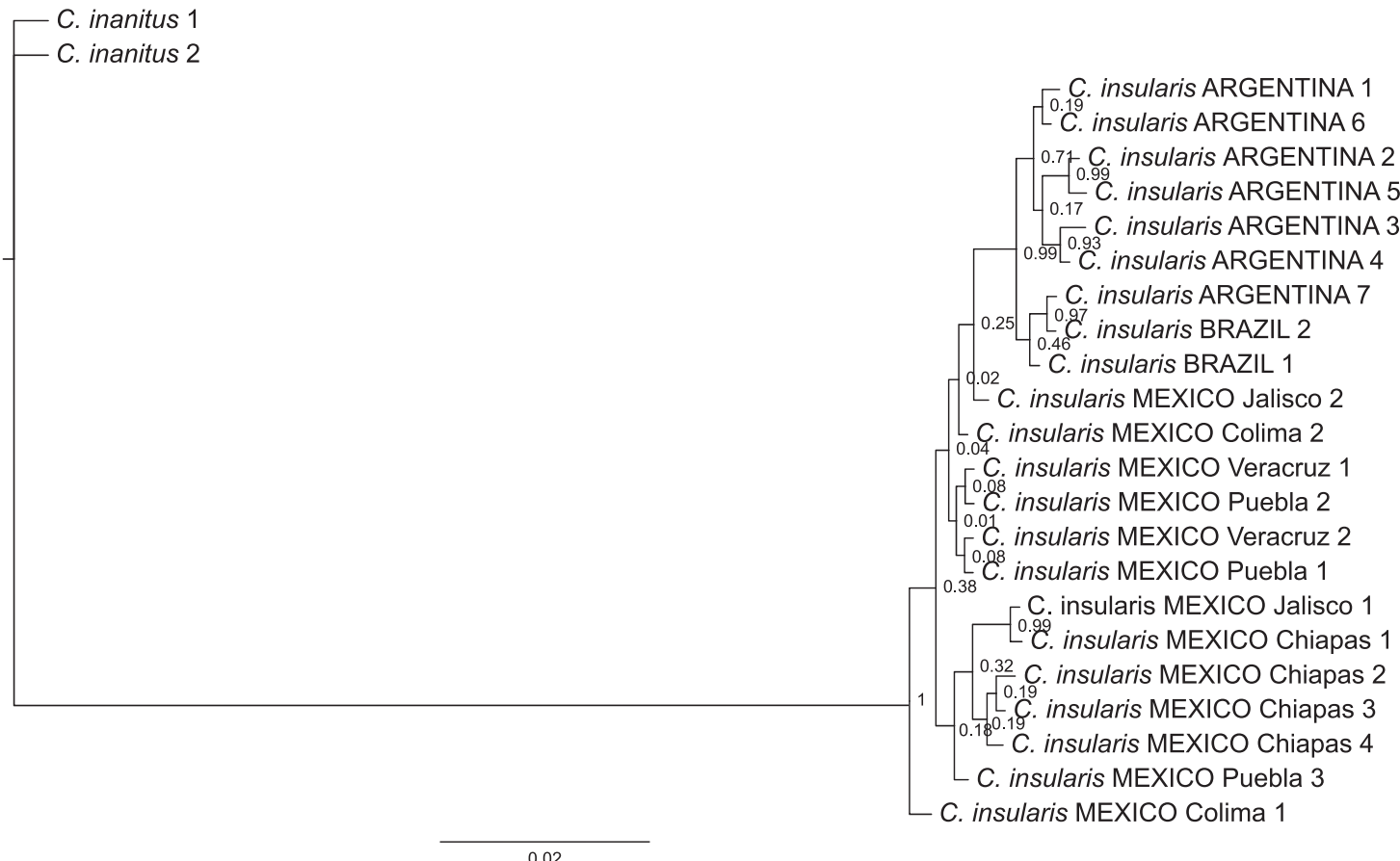

Fig. 1. Majority-rule phylogenetic tree resulting from the Bayesian inference analysis using a partitioned supermatrix approach (see Materials and Methods) for C. insularis. BPPs are indicated on each node. This tree was obtained from the analysis of three mitochondrial markers: $16 \mathrm{~S}, \mathrm{COI}$, and Cyt $b$.

2,591 in total), among which 43 characters were parsimony-informative. Under the MP criterion, the heuristic search resulted into 201 equally most parsimonious trees of 154 steps $(\mathrm{CI}=0.948 ; \mathrm{RI}=0.929 ; \mathrm{RC}=$ $0.880 ; \mathrm{HI}=0.051)$. Based on the probabilistic criteria, the best-fit model for Campoletis was the HasegawaKishino-Yano (HKY) with an alpha parameter for the shape of the gamma distribution to account for amongsite rate heterogeneity and a proportion of invariable site. The topologies produced during the two ML searches were identical and fully congruent with the Bayesian Inference partitioned-analysis, in which the best-fit model for individual DNA partitions were $\mathrm{HKY}+\mathrm{G}$ for $16 \mathrm{~S}$, HKY for $28 \mathrm{~S}, \mathrm{HKY}+\mathrm{I}$ for COI, and K2P for ITS. In this latter analysis, average standard deviation of split frequencies reached $1 \%$ after 100,000 generations, thus discarding the first 1,000 trees. ESS was $>200$ for all parameters.

Topologies. The topologies unraveled with the different methods were highly similar therefore we show only the phylogenetic trees resulting from the Bayesian inference analyses (see Fig. 1 for C. insularis and Fig. 2 for Campoletis spp.). For C. insularis, the group including individuals coming from Argentina and Brazil is monophyletic and nested in the Mexican group $(\mathrm{BPP}=0.99)$. Within the SouthAmerican group, no clear structure can be observed. The Mexican group shows no clear structure either and exhibits paraphyletic origins together with the South-American group. However, this paraphyly is not well supported $(\mathrm{BPP}=0.38)$. For Campoletis spp., our results demonstrate that Campoletis sonorensis forms a paraphyletic group with well supported clades $(\mathrm{BPP}=1)$. Similarly, $C$. grioti exhibits paraphyly $(\mathrm{BPP}=1)$. In contrast, C. flavicincta is monophyletic $(\mathrm{BPP}=1)$. No clear geographic structure is observed in C. sonorensis. However, the three Canadian individuals collected on T. ni come out in an entirely separate clade $(\mathrm{BPP}=0.98)$.

\section{Discussion}

In C. insularis, the group of individuals coming from South America is clearly nested into the Mexican group, implying that South American wasps might derive from Mesoamerican ancestors. The monophyly of the South American group contrasts with the paraphyletic origins of the Mexican group. South American populations may therefore have arisen from a single colonization event. This result should, however, be taken with caution because the choice of the outgroup as C. inanitus (i.e., the closest to $C$. insularis in our phylogeny) has been based only on sequences of about a dozen published Chelonus taxa, whereas this genus is estimated to comprise several hundreds of species. Nonetheless, it is worth noting that the Mexican group is as diversified as the South American group, which, in conjunction with the previous notion, argues for a possible north-south migration. Yet, a more extensive sampling in North America, as well as a more accurate identification of the closest outgroup (once a complete phylogeny of Chelonus has been 


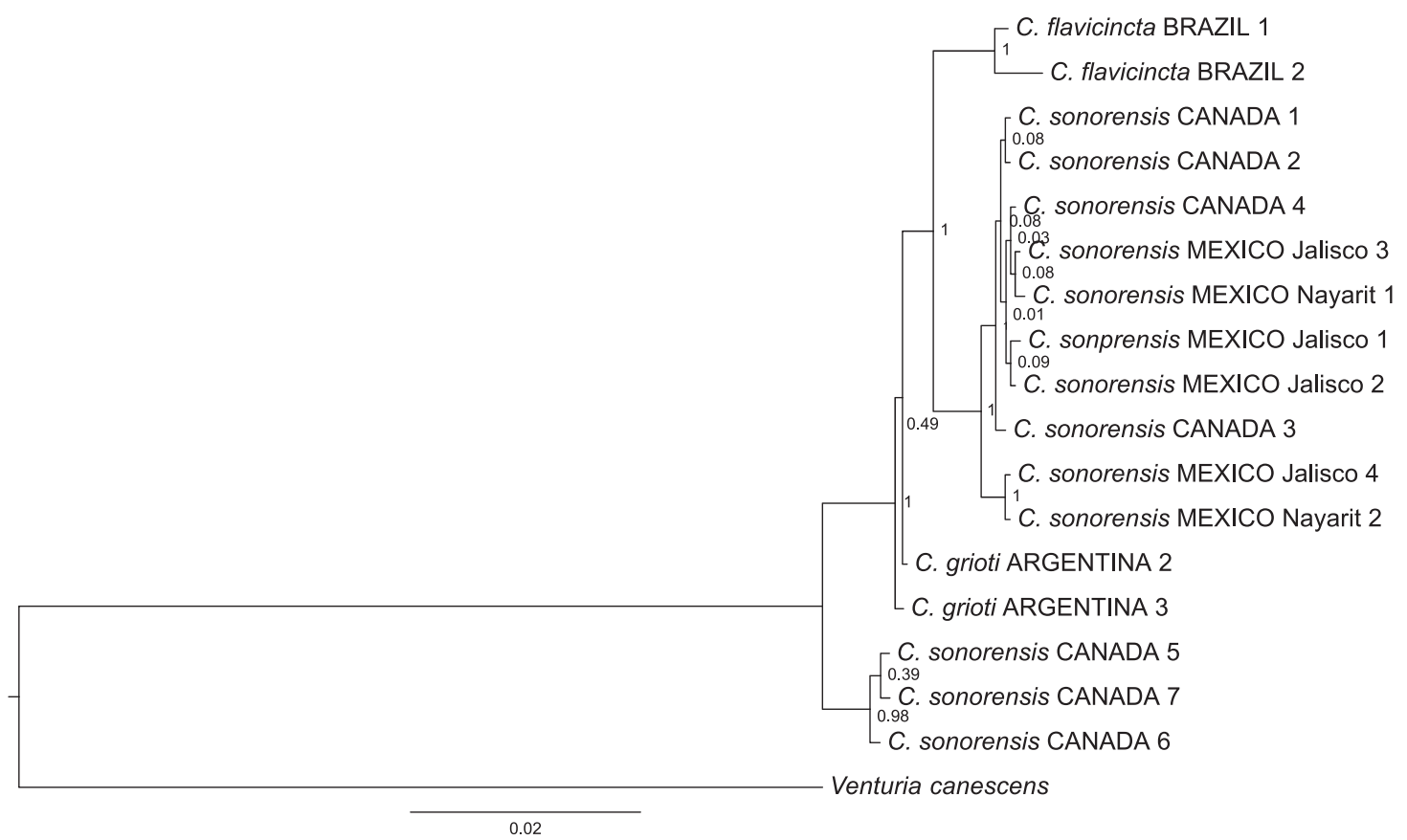

Fig. 2. Majority-rule phylogenetic tree resulting from the Bayesian inference analysis using a partitioned supermatrix approach (see Materials and Methods) for Campoletis spp. BPPs are indicated on each node. This tree was obtained from the analysis of two mitochondrial (16S and COI) and two nuclear (28S rRNA and ITS2) markers.

published) will be necessary to determine the exact geographic origins of this species. The high level of admixture at a regional scale (i.e., the very weak local fine structure) indicates considerable gene flow between populations. For instance, individual one from Jalisco and individual one from Chiapas come out together in a very well supported clade $(\mathrm{BPP}=0.99)$ (i.e., sequences from the two individuals are identical in all partitions) despite being geographically distant from $>1,000 \mathrm{~km}$. Similarly, individual seven from Argentina and individual two from Brazil are identical for all partitions even though they come from two distant locations separated by $>1,300 \mathrm{~km}$.

Regarding C. sonorensis, the data strongly support the paraphyly of this taxon. The apparent paraphyly of C. grioti might be mostly due to a small sampling size. Indeed, it is not supported by Bayesian posterior probability $(\mathrm{BPP}<0.5)$. Nonetheless, there was a striking difference between the three Canadian individuals ( 5 , 6, and 7), which were collected on T. $n i$, and the other Canadian individuals that emerged from S. frugiperda $(\mathrm{BPP}=1)$, implying that use of different host species may strongly affect evolutionary processes and may have lead to genetic differentiation. Offspring of wasps collected from the two hosts also were compared morphologically and all confirmed to be C. sonorensis (Dr. A. Bennett, Canadian National Collection). In the laboratory, the two lineages (i.e., $C$. sonorenis specimens on S. frugiperda and C. sonorensis specimens on T. ni) were found to successfully parasitize the two hosts, but they both did better on $S$. frugiperda (H.M., unpublished data). This would ex- plain why C. sonorensis has been very rarely reported as parasitizing T. ni (Murillo 2008). However, in southwestern Ontario, Canada, from where we obtained our Canadian individuals, C. sonorensis is the most abundant parasitoid of T. ni on tomato in the field and greenhouses. Therefore, we speculate that the clear separation in Canada of C. sonorensis from S. frugiperda and C. sonorensis from T. ni is the result of an ancient adaptation of a biotype to the early seasonal occurrence of $T$. ni, perhaps through a synchronized diapause. Trichoplusia ni is present in high numbers from May, whereas $S$. frugiperda is present only starting midsummer (Murillo 2008).

Molecular tools once again proved useful to bring cryptic species to the fore, as it was the case in several previous studies (Hebert et al. 2004, Smith et al. 2006, Burns et al. 2008). There was, however, no indication of local fine structure. Indeed, C. sonorensis individuals coming from close geographic locations, i.e., individuals three and four from Jalisco (Mexico), and individuals one and two from Nayarit (Mexico), pair-up in different very well-supported clades $(\mathrm{BPP}=1)$. Moreover, if we only take into consideration individuals of $C$. sonorensis emerging from S. frugiperda, there is no evidence for structure at the scale of the North American continent.

Hence, the low level of genetic structure observed at the local Mexican scale by using microsatellites (Jourdie et al. 2010) was confirmed at a larger scale with the use of other sequence markers. Interpopulation movements seem to be very important even over very large distances. Whereas patterns of popu- 
lation structure found in different Mesoamerican insect pests have been explained by farmers' practices and contemporaneous trade of plant parts such as seeds (Alvarez et al. 2007, Restoux et al. 2010), humanmediated dispersal can be ruled out in the context of these two parasitoid species, which are not able to disperse in association with the plant. However, wind is a likely mode of dispersal for these insects as they are too small and fragile to fly over such distances. Wind is known to play an important role in dispersal of small flying insects (Compton 2002). Dispersal by moving air largely dictates direction and distance of migration to small insects, which can be expected to reflect in the genetic population structure (Dudley 2000).

The observed absence of genetic structure might also result from a keen ability of these insects to adapt to environmental changes and therefore to readily invade new environments (Hengeveld 1989, Kareiva 1996). This adaptability enhances their potential as effective biological control agents in new areas of release. Finally, cryptic taxa brought to evidence in this study may have different host ranges and represent new candidates for biological control.

\section{Acknowledgments}

We are grateful to the Mexican students and to Ivan Hiltpold who helped with field collections. This study was supported by the Swiss National Center of Competence in Research "Plant Survival" and grant 3100A0-107974 from the Swiss National Science Foundation.

\section{References Cited}

Alvarez, N., M. Hossaert-McKey, G. Restoux, A. DelgadoSalinas, and B. Benrey. 2007. Anthropogenic effects on population genetics of phytophagous insects associated with domesticated plants. Evolution 61: 2986-2996.

Barton, N. H., and I. Wilson. 1996. Genealogies and geography, pp. 23-56. In P. H. Harvey, A.J.L. Brown, J. Maynard Smith, and S. Nee [eds.], New uses for new phylogenies. Oxford University Press, Oxford, United Kingdom.

Belshaw, R., and D.L.J. Quicke. 1997. A molecular phylogeny of the Aphidiinae (Hymenoptera: Braconidae). Mol. Phylogenet. Evol. 7: 281-293.

Burns, J. M., D. H. Janzen, M. Hajibabaei, W. Hallwachs, and P.D.N. Hebert. 2008. DNA barcodes and cryptic species of skipper butterflies in the genus Perichares in Area de Conservacion Guanacaste, Costa Rica. Proc. Natl. Acad. Sci. USA 105: 6350-6355.

Campbell, B. C., J. D. Steffen-Campbell, and J. H. Werren. 1993. Phylogeny of the Nasonia species complex ( $\mathrm{Hy}-$ menoptera: Pteromalidae) inferred from an internal transcribed spacer (ITS2) and 28S rDNA sequences. Insect Mol. Biol. 2: 225-237.

Chapman, J. W., T. Williams, A. M. Martínez, J. Cisneros, P. Caballero, R. D. Cave, and D. Goulson. 2000. Does cannibalism in Spodoptera frugiperda (Lepidoptera: Noctuidae) reduce the risk of predation? Behav. Ecol. Sociobiol. 44: 548-558.

Chesser, R. K. 1991a. Gene diversity and female philopatry. Genetics 127: 437-447.
Chesser, R. K. 1991b. Influence of gene flow and breeding tactics on gene diversity within populations. Genetics 129: 573-583.

Compton, S. G. 2002. Sailing with the wind: dispersal by small flying insects, pp. 113-153. In J. M. Bullock, R. E. Kenward, and R. Hails [eds.], Dispersal ecology: 42nd Symposium of the British Ecological Society, 2-5 April 2001, University of Reading, Reading, United Kingdom. Blackwell, Oxford, United Kingdom.

Dowton, M., and A. D. Austin. 1994. Molecular phylogeny of the insect order Hymenoptera: apocritan relationships. Proc. Natl. Acad. Sci. USA. 91: 9911-9915.

Dudley, R. 2000. The evolutionary physiology of animal flight: paleobiological and present perspectives. Annu. Rev. Physiol. 62: 135-155.

Hall, T. A. 1999. BioEdit: a user-friendly biological sequence alignment [ed.], and analysis program for Windows 95/98/NT. Nucleic Acids Symp. Ser. 41: 95-98.

Hebert, P.D.N., E. H. Penton, J. M. Burns, D. H. Janzen, and W. Hallwachs. 2004. Ten species in one: DNA barcoding reveals cryptic species in the Neotropical skipper butterfly Astraptes fulgerator. Proc. Natl. Acad. Sci. USA 101: 14812-14817.

Hengeveld, R. 1989. Caught in an ecological web. Oikos 54: 15-22

Hoballah, M. E., T. Degen, D. Bergvinson, A. Savidan, and T.C.J. Turlings. 2004. Occurrence and direct control potential of parasitoids and predators of the Fall armyworm (Lepidoptera: Noctuidae) on maize in the subtropical lowlands of Mexico. Agric. For. Entomol. 6: 83-88.

Huelsenbeck, J. P., and F. Ronquist. 2001. MRBAYES: Bayesian inference of phylogenetic trees. Bioinformatics 17: $754-755$.

Jobb, G. 2008. TREEFINDER, version of June 2008 computer program, by G. Jobb. (Distribute by author at www. treefinder.de.)

Jourdie, V., N. Alvarez, and T.C.J. Turlings. 2008. Identification of seven species of hymenopteran parasitoids of Spodoptera frugiperda, using polymerase chain reaction amplification and restriction enzyme digestion. Agric. For. Entomol. 10: 129-136.

Jourdie, V., A. Alvarez, J. Molina-Ochoa, T. Williams, D. Bergvinson, B. Benrey, T.C.J. Turlings, and P. Franck. 2010. Population genetic structure of two primary parasitoids of Spodoptera frugiperda (Lepidoptera), Chelonus insularis and Campoletis sonorensis (Hymenoptera): is host plant important? Mol. Ecol. 19: 2168-2179.

Kareiva, P. 1996. Contributions of ecology to biological control. Ecology 77: 1963-1964.

Kranz, J., H. Schmutterer, and W. Koch. 1977. Diseases, pests and weeds in tropical crops. Verlag Paul Parey, Berlin, Germany.

Molina-Ochoa, J., J. E. Carpenter, E. A. Heinrichs, and J. E. Foster. 2003. Parasitoids and parasites of Spodoptera frugiperda (Lepidoptera: Noctuidae) in the Americas and Caribbean Basin: an inventory. Fla. Entomol. 86: 254-289.

Murillo, H. 2008. Evaluation of the larval endoparasitoid Campoletis sonorensis Cameron (Hymenoptera: Ichneumonidae) as a biocontrol agent of the cabbage looper. M.S. thesis, University of Windsor, Windsor, ON, Canada.

Murua, G., J. Molina-Ochoa, and C. Coviella. 2006. Population dynamics of the fall armyworm, Spodoptera frugiperda (Lepidoptera: Noctuidae) and its parasitoids in northwestern Argentina. Fla. Entomol. 89: 175-182.

Nixon, K. C. 1999. The Parsimony Ratchet, a new method for rapid parsimony analysis. Cladistics 15: 407-414.

Nylander, J.A.A. 2004. MrAIC. pl. computer program, version by J.A.A. Nylander. (Distributed by author at Evo- 
lutionary Biology Center, Uppsala University, Uppsala, Sweden.)

Raes, J., and Y. Van de Peer. 1999. ForCon: a software tool for the conversion of sequence alignments. Embnet. News. 6: 10-12.

Rambaut, A., and A. J. Drummond. 2005. Tracer, version 1.3: MCMC Trace Analysis Tool computer program, version by A. Rambaut and A. J. Drummond. Evolutionary Biology Group, University of Oxford, United Kingdom. (http:/ / evolve.zoo.ox.ac.uk).

Restoux, G., M. Hossaert-McKey, B. Benrey, and N. Alvarez. 2010. The effect of host plant and isolation on the genetic structure of a phytophagous beetle. Eur. J. Entomol. 107(3): 299-304.

Sikes, D. S., and P. O. Lewis. 2001. PAUPRat: a tool to implement parsimony ratchet searches using PAUP*, beta software, version 1 computer program, version by D. S. Sikes and P. O. Lewis. Sinauer Associates, Sunderland, MA.

Simon, C., F. Frati, A. Beckenbach, B. Crespi, H. Liu, and P. Flook. 1994. Evolution, weighting, and phylogenetic utility of mitochondrial gene sequences and a compilation of conserved polymerase chain reaction primers. Ann. Entomol. Soc. Am. 87: 651-701.

Smith, M. A., N. E. Woodley, D. H. Janzen, W. Hallwachs, and P.D.N. Hebert. 2006. DNA barcodes reveal cryptic host-specificity within the presumed polyphagous members of a genus of parasitoid flies (Diptera: Tachinidae). Proc. Natl. Acad. Sci. USA 103: 3657-3662.

Stamatakis, A. 2006. RAxML-VI-HPC: maximum likelihoodbased phylogenetic analyses with thousands of taxa and mixed models. Bioinformatics 22: 2688-2690.
Stamatakis, A., P. Hoover, and J. Rougemont. 2008. A Rapid Bootstrap Algorithm for the RAxML Web Servers. Syst. Biol. 57: 758-771.

Swofford, D. L. 2002. PAUP*: phylogenetic analysis using parsimony (*and other methods), version 4 computer program, version by Swofford, D. L., Sunderland, MA.

Thompson, J. D., D. G. Higgins, and T. J. Gibson. 1994. Clustal-W: improving the sensitivity of progressive multiple sequence alignment through sequence weighting, position specific gap penalties and weight matrix choice. Nucleic Acids Res. 22: 4673-4680.

Waser, P. M., and C. Strobeck. 1998. Genetic signatures of interpopulation dispersal. Trends Ecol. Evol. 13: 43-44.

White, T. J., T. Bruns, S. Lee, and J. Taylor. 1990. Amplification and direct sequencing of fungal ribosomal RNA genes for phylogenetics, pp. 315-322. In M. A. Innis, D. H. Gelfand, J. J. Sninsky, and T. J. White [eds.], PCR protocols: a guide to methods and application. Academic, New York.

Whitfield, J. B. 1997. Molecular and morphological data suggest a common origin for the polydnaviruses among braconid wasps. Naturwissenschaften 84: 502-507.

Wiens, J. J., and T. W. Reeder. 1995. Combining data sets with different numbers of taxa for phylogenetic analysis. Syst. Biol. 44: 548-558.

Wyckhuys, K.A.G., and R. J. O’Neil. 2006. Population dynamics of Spodoptera frugiperda Smith (Lepidoptera: Noctuidae) and associated arthropod natural enemies in Honduran subsistence maize. Crop Prot. 25: 1180-1190.

Received 27 October 2009; accepted 9 June 2010. 